\title{
Formation and Properties of Oxide Coatings with Immobilized Zeolites Obtained by Plasma Electrolytic Oxidation of Aluminum
}

\author{
Kristina Mojsilović ${ }^{1}\left(\mathbb{D}\right.$, Uroš Lačnjevac $^{2}(\mathbb{D})$, Srna Stojanović ${ }^{3}$, Ljiljana Damjanović-Vasilić ${ }^{3}$, \\ Stevan Stojadinović ${ }^{1}$ (D) and Rastko Vasilić ${ }^{1, *(D)}$
}

1 Faculty of Physics, University of Belgrade, Studentski trg 12-16, 11000 Belgrade, Serbia; kristina.mojsilovic@ff.bg.ac.rs (K.M.); sstevan@ff.bg.ac.rs (S.S.)

2 Institute for Multidisciplinary Research, University of Belgrade, Kneza Višeslava 1, 11030 Belgrade, Serbia; uros.lacnjevac@imsi.bg.ac.rs

3 Faculty of Physical Chemistry, University of Belgrade, Studentski trg 12-16, 11000 Belgrade, Serbia; srna@ffh.bg.ac.rs (S.S.); ljiljana@ffh.bg.ac.rs (L.D.-V.)

* Correspondence: rastko.vasilic@ff.bg.ac.rs; Tel.: +381-11-7158161; Fax: +381-11-3282619

check for updates

Citation: Mojsilović, K.; Lačnjevac, U.; Stojanović, S.; Damjanović-Vasilić, L.; Stojadinović, S.; Vasilić, R. Formation and Properties of Oxide Coatings with Immobilized Zeolites Obtained by Plasma Electrolytic Oxidation of Aluminum. Metals 2021, 11, 1241. https://doi.org/10.3390/ met11081241

Academic Editor: Jianqiang Wang

Received: 12 July 2021

Accepted: 2 August 2021

Published: 5 August 2021

Publisher's Note: MDPI stays neutral with regard to jurisdictional claims in published maps and institutional affiliations.

Copyright: (c) 2021 by the authors. Licensee MDPI, Basel, Switzerland. This article is an open access article distributed under the terms and conditions of the Creative Commons Attribution (CC BY) license (https:// creativecommons.org/licenses/by/ $4.0 /)$.

\begin{abstract}
In this paper, we employed plasma electrolytic oxidation (PEO) of aluminum in a water solution of sodium tungstate $\left(\mathrm{Na}_{2} \mathrm{WO}_{4} \cdot 2 \mathrm{H}_{2} \mathrm{O}\right)$ with the addition of the pure and Ce-loaded zeolites clinoptilolite and $13 \mathrm{X}$ for the preparation of oxide coatings. The obtained coatings were characterized with respect to their morphologies and chemical and phase compositions using scanning electron microscopy coupled with energy-dispersive $\mathrm{X}$-ray spectroscopy, atomic force microscopy, and X-ray diffraction. The prepared coatings contained $\gamma$-alumina, $\mathrm{WO}_{3}$, and metallic tungsten. The surface morphologies of the obtained coatings strongly depended on the PEO processing time; the roughness of all coatings increased with PEO time, while porosity decreased with PEO processing time as a result of microdischarge coalescence and growth. All coatings contained elements originating from the substrate and from the electrolytes. Coatings containing zeolites with Ce showed higher photoactivity than those with immobilized pure zeolites. The highest photocatalytic activity levels were observed for coatings containing immobilized Ce-exchanged clinoptilolite processed for $10 \mathrm{~min}$. It was observed that both clinoptilolite and 13X zeolites improved the features of the PEO coatings in a similar manner, making natural and abundant clinoptilolite an excellent candidate for various applications.
\end{abstract}

Keywords: zeolites; plasma electrolytic oxidation; photocatalysis; oxide coatings

\section{Introduction}

The availability of safe and clean water is vital for human health and the ecosystem, meaning management of wastewater is of crucial importance. Water quality has been degraded around the world by increased amounts of industrial discharge and agricultural runoff, and even if the wastewater is collected and treated, the efficiency of that treatment can vary depending on the system used. A promising system of wastewater treatment that has been receiving a growing interest is decontamination through visible-light photocatalysis [1-3].

The most common way in which the photocatalytic process is executed is on slurry systems containing suspended nanoparticles [4,5]. These systems have high active surface areas, resulting in high decomposition rates [6], although the post-treatment removal of nanoparticle suspensions has proven to be a costly and time-consuming process. Consequently, a lot of attention has been given to techniques that can immobilize nanoparticles in oxide coatings, which can act as efficient photocatalysts in low-cost substrates [7,8]. Previously published results have shown that plasma electrolytic oxidation (PEO) is suitable for such tasks [7-9]. 
PEO process, originating from conventional anodizing, is an eco-friendly and efficient surface altering technique commonly employed to form ceramic-like coatings on valve metals ( $\mathrm{Al}, \mathrm{Mg}$, Ti etc.) and their alloys [10-12]. The coatings are formed under high voltages, where short-lived discharges occur on the substrate surface, leading to conversion of the metal to its oxide. The main characteristics of these PEO coatings are mirrored in their microstructure and composition, which can be shaped through process parameters and electrolyte properties. Modifying the electrolyte composition by adding particles to it is an effective way to improve the coatings' attributes, such as their anti-corrosion properties, porosity, and photocatalytic activity [13].

Zeolites are microporous crystalline solids with well-defined structures involving Si, $\mathrm{Al}$, and $\mathrm{O}$ in their framework and cations. Many zeolites occur naturally as minerals, while others are synthetic and are manufactured for a specific use. Their unique porous properties make zeolites viable for a variety of applications, for example in ion exchangers, sorbents, oxidation and hydrogeneration reactions, supports for catalytic metals, and molecular sieves [14-19]. Due to their photochemical stability and large surface areas combined with their channel size, zeolites are used as nanocontainers of semiconducting or photoactive guests, such as $\mathrm{CeO}_{2}[15,16]$; however, recent research has shown that zeolites can act as photocatalysts themselves [17]. Consequently, combining the two mentioned properties of zeolites can lead to pronounced photocatalytic activity, which is even comparable to $\mathrm{TiO}_{2}$ photocatalysts [18].

Despite the fact that there are published studies of composite coatings with zeolites immobilized by PEO [20,21], these have mostly focused on enhancing the corrosion properties of the obtained coatings. In contrast to our recently published paper [22] that also investigated composite coatings with zeolites, we decided to perform continuous DC PEO processing aiming at achieving higher surface roughness and porosity, which promote the photocatalytic and photoluminescent properties of the obtained coatings. Additionally, the selection of sodium tungstate electrolyte was made because it has been shown that $\mathrm{PEO}$ processing in such electrolyte results in the decrease of the breakdown voltage and production of thinner PEO coatings with better photocatalytic properties [23-25].

In this paper, the focus is on the composite PEO coatings containing naturally occurring zeolite-clinoptilolite with and without Ce ion exchange and synthetic 13X zeolite, also with and without Ce. We decided to use these two zeolites because clinoptilolite is not a pure phase material, unlike the synthetic $13 \mathrm{X}$ zeolite. Photocatalytic activity is tested through simulated sunlight irradiation of the coatings in methyl orange. An investigation of the surface morphologies and chemical and phase compositions of the obtained oxide coatings was conducted using scanning electron microscopy coupled with energydispersive X-ray spectroscopy (SEM/EDS), atomic force microscopy (AFM), and X-ray diffraction (XRD). The degradation stability of the obtained coatings was demonstrated by linear polarization testing and Tafel plots.

\section{Materials and Methods}

Rectangular aluminum samples (1050 A alloy) were used as the anode material, which were sealed in insulation resin, leaving an active surface area of $4.5 \mathrm{~cm}^{2}$ accessible to the electrolytes. A stainless steel sheet measuring approx. $20 \mathrm{~cm}^{2}$ was used as the cathode in all experiments. The starting zeolites used in this work were HEU-type natural zeolite clinoptilolite $\left((\mathrm{Na}, \mathrm{K})_{6} \mathrm{Si}_{30} \mathrm{Al}_{6} \mathrm{O}_{72} \cdot \mathrm{nH}_{2} \mathrm{O}, \mathrm{Si} / \mathrm{Al}=5\right)$ originated from the Zlatokop mine in Vranjska Banja, Serbia, as well as synthetic FAU-type zeolite Na-13X ( $\mathrm{Na}_{87}\left[\mathrm{Al}_{87} \mathrm{Si}_{105} \mathrm{O}_{384}\right]$, $\mathrm{Si} / \mathrm{Al}=1.2$ ) produced by Union Carbide(Seadrift, TX, USA). Cerium-containing forms of zeolites were obtained using a conventional aqueous ion exchange procedure in dilute solution [26]. The average particle sizes of the zeolite powders used in this study were $6 \pm 1 \mu \mathrm{m}$ for pure and Ce-exchanged clinoptilolite and $2.5 \pm 0.5 \mu \mathrm{m}$ for pure and Ceexchanged 13X zeolite, as estimated from SEM micrographs of zeolite powders. The higher average particle size of the clinoptilolite was related to its agglomeration into elongated spherical particles, while 13X-faceted spherical particles showed lower agglomeration. 
The PEO process was carried out in an electrolytic cell containing water solution of $0.01 \mathrm{M}$ sodium tungstate $\left(\mathrm{Na}_{2} \mathrm{WO}_{4} \cdot 2 \mathrm{H}_{2} \mathrm{O}\right)$, which was used as a supporting electrolyte with the addition of $1 \mathrm{~g} / \mathrm{L}$ of clinoptilolite, clinoptilolite exchanged with $\mathrm{Ce}, 13 \mathrm{X}$, and 13X exchanged with Ce zeolites (Table 1). The electrolyte was prepared using doubledistilled and deionized water and PA (pro analysis)-grade chemical compounds. During PEO, electrolytes circulated through the chamber-reservoir system and the temperature of the electrolyte was kept under $25^{\circ} \mathrm{C}$. The PEO was conducted under a constant current density of $50 \mathrm{~mA} / \mathrm{cm}^{2}$ for 5, 7, 10, and $15 \mathrm{~min}$ using an Agilent Technologies N5752A (Agilent, Santa Clara, CA, USA)(0-600 V, 1.3 A, 780 W) DC power source. After the PEO, samples were rinsed in distilled water and dried in hot air stream. Voltage evolution was recorded using a Tektronix TDS 2022 (Beaverton, OR, USA) digital storage oscilloscope and a high voltage probe, which was connected directly to the anode and cathode of the electrolytic cell.

Table 1. Sample designation and electrolytes used for PEO processing.

\begin{tabular}{cc}
\hline Sample Name & Electrolyte \\
\hline $\mathrm{Cli}$ & $\mathrm{SE}+1 \mathrm{~g} / \mathrm{L}$ clinoptilolite \\
$\mathrm{Cli}+\mathrm{Ce}$ & $\mathrm{SE}+1 \mathrm{~g} / \mathrm{L}$ clinoptilolite $+\mathrm{Ce}$ \\
$13 \mathrm{SE}+1 \mathrm{~g} / \mathrm{L} 13 \mathrm{X}$ \\
$13 \mathrm{X}+\mathrm{Ce}$ & $\mathrm{SE}+1 \mathrm{~g} / \mathrm{L} 13 \mathrm{X}+\mathrm{Ce}$ \\
$\mathrm{SE}$ & $0.01 \mathrm{M} \mathrm{Na} \mathrm{WO}_{4} \cdot 2 \mathrm{H}_{2} \mathrm{O}$ \\
\hline
\end{tabular}

A scanning electron microscope (SEM; Tescan VEGA TS 5130 MM with BSE detector; Tescan, Brno, Czech Republic) was used to examine the surface morphology of the PEO layers, while their chemical composition was analyzed with an energy-dispersive spectrometer (EDS: Oxford Instruments, High Wycombe, UK) coupled with SEM. An atomic force microscope (AFM; Veeco Instruments, model Dimension V: Veeco, Plainview, NY, USA) was used to further characterize the morphology and mechanical properties (surface roughness) of the obtained coatings, while porosity was estimated from SEM micrographs using ImageJ software.

A Rigaku Ultima IV diffractometer (Rigaku, Tokyo, Japan) with an Ni-filtered CuK $\mathrm{K}_{\alpha}$ radiation source was used for crystal phase identification. Crystallographic data were collected in Bragg-Brentano mode in the $2 \theta$ range from $10^{\circ}$ to $70^{\circ}$ with a scanning rate of $2^{\circ} / \mathrm{min}$.

Photoluminescence (PL) spectral measurements were performed on a Horiba Jobin Yvon Fluorolog FL3-22 spectrofluorometer (Horiba, Edison, NJ, USA) at room temperature, with a $450 \mathrm{~W}$ xenon lamp as the excitation light source in the range of 305 to $540 \mathrm{~nm}$.

The photocatalytic activity of the obtained coatings on Al substrate was investigated by photodecomposition of methyl orange $(\mathrm{MO})$ at room temperature. Samples (approx. $2.25 \mathrm{~cm}^{2}$ exposed to irradiation) were immersed into $10 \mathrm{~mL}$ of $8 \mathrm{mg} / \mathrm{L}$ aqueous $\mathrm{MO}$ solution and placed on a perforated holder $5 \mathrm{~mm}$ above the bottom of the reactor (jacketed $50 \mathrm{~mL}$ glass beaker of constant temperature) with a magnetic stirrer underneath. Prior to irradiation, the solution and the catalyst were magnetically stirred in the dark until adsorption-desorption equilibrium was reached (30 min). Afterwards, the MO solution was illuminated using a lamp that simulates the solar spectrum (Osram Vitalux lamp, $300 \mathrm{~W}$ ), which was placed $25 \mathrm{~cm}$ above the top surface of the solution. Every hour, a fixed amount $(1 \mathrm{~mL})$ of the MO solution was removed to measure the absorption at $464 \mathrm{~nm}$ using an Agilent Carry 60 UV-Vis spectrophotometer (Agilent, Sannta Clara, CA, USA). The absorbance was converted to $\mathrm{MO}$ concentration in accordance with the standard curve, showing a linear relationship between the concentration and the absorbance at this wavelength. Afterwards, each measurement aliquot was returned back to the photocatalytic reactor. Prior to the photocatalysis, the $\mathrm{MO}$ solution was tested for photolysis in the absence of the photocatalyst and the lack of change in the MO concentration after $6 \mathrm{~h}$ of irradiation 
revealed that the $\mathrm{MO}$ was stable under applied conditions and that degradation was only due to the presence of the photocatalyst.

For degradation stability testing of the samples, a three-electrode system was employed, with a PEO sample as the working electrode, a saturated calomel electrode (SCE) as the reference electrode, and a graphite electrode as the counter electrode. The corrosion rates in aerated $3.5 \% \mathrm{NaCl}$ solution of the PEO layers were determined using extrapolation of potentiodynamic curves to the open circuit potential (OCP) following its establishment (after approximately $1 \mathrm{~h}$ ) with a Bio-Logic SP-240 (Seyssinet-Pariset, France) potentiostat and EC-Lab corrosion software. Linear polarization tests were conducted from $-0.25 \mathrm{~V}$ to $0.25 \mathrm{~V}$ around the $\mathrm{OCP}$, with a potential sweep of $1 \mathrm{mV} / \mathrm{s}$ over a $0.2 \mathrm{~cm}^{2}$ surface.

\section{Results and Discussion}

The time evolution of the anodization voltage during PEO in supporting electrolytes with and without the addition of pure and Ce-exchanged zeolites is shown in Figure 1. During the first $120 \mathrm{~s}$ of the process, the voltage increases linearly with time. This fragment of the PEO process is similar to conventional anodizing, and during this time a relatively uniform increase of the barrier layer takes place. The uniform film thickening is ended by dielectric breakdown, characterized by deflection from linearity of the voltage versus time curve when the breakdown voltage occurs. A further increase of the voltage starts a trend of visible microdischarges appearing across the sample's surface. Figure 1 undoubtedly shows that the addition of particles to the supporting electrolytes decreases the breakdown voltage, but does not change the overall shape of the voltage-time curve, suggesting that the deposition mechanism remains the same. The decrease of the breakdown voltage is related to an increase in electrical conductivity of the electrolyte caused by the addition of the zeolites [13,22].

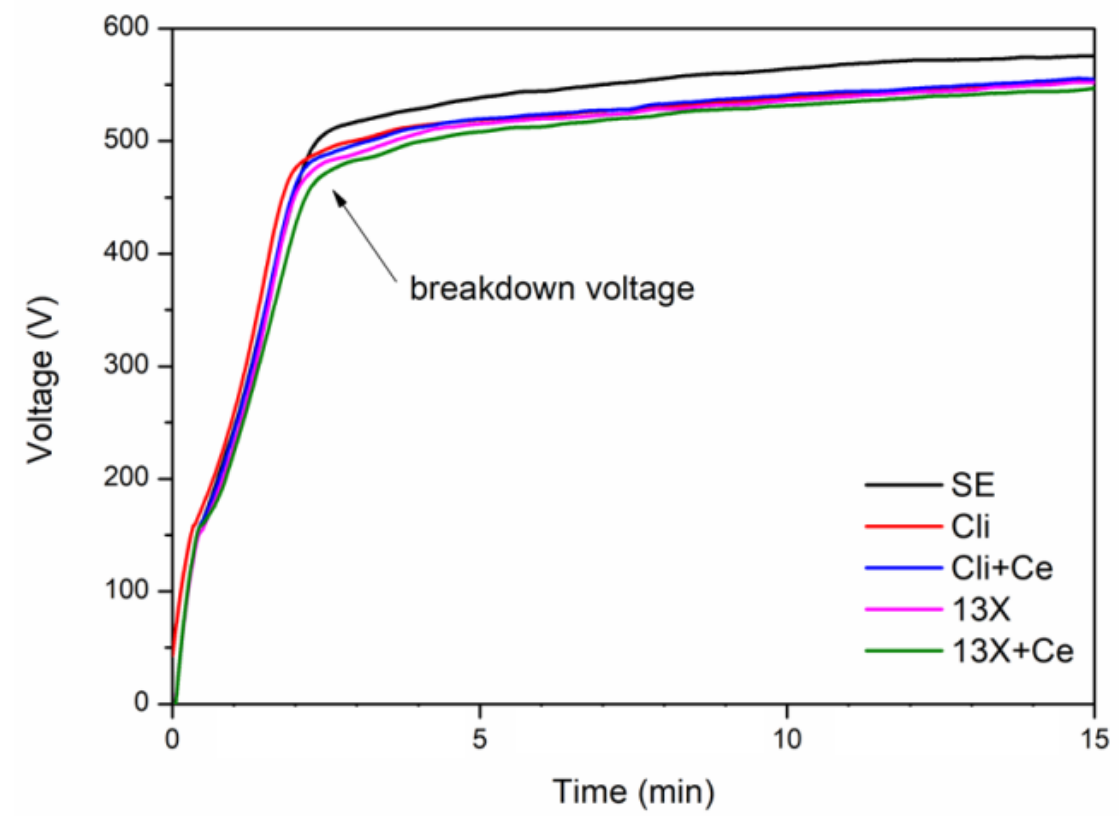

Figure 1. Time evolution of anodizing voltage during PEO.

\subsection{Morphologies and Chemical and Phase Compositions of PEO Coatings}

XRD patterns of oxide coatings containing clinoptilolite obtained after various $\mathrm{PEO}$ times and of PEO coatings containing different zeolites at $15 \mathrm{~min}$ of PEO processing are presented in Figure 2. 
(a)

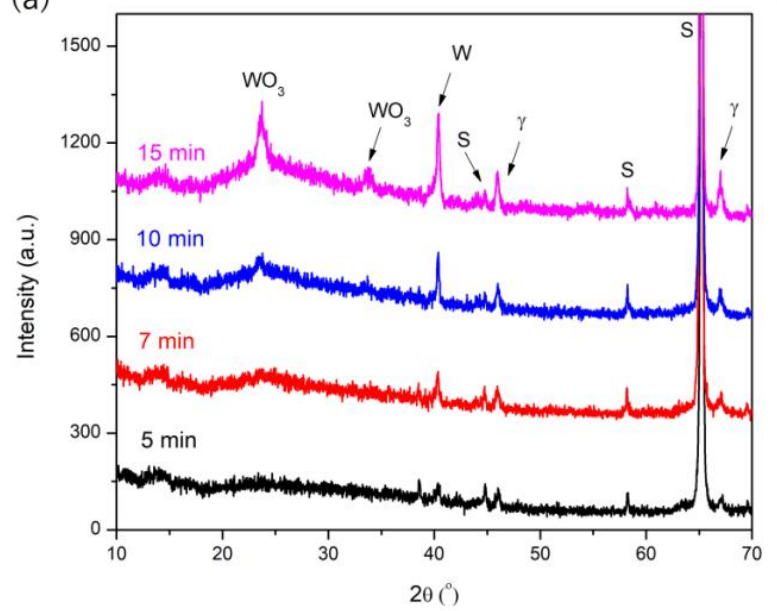

(b)

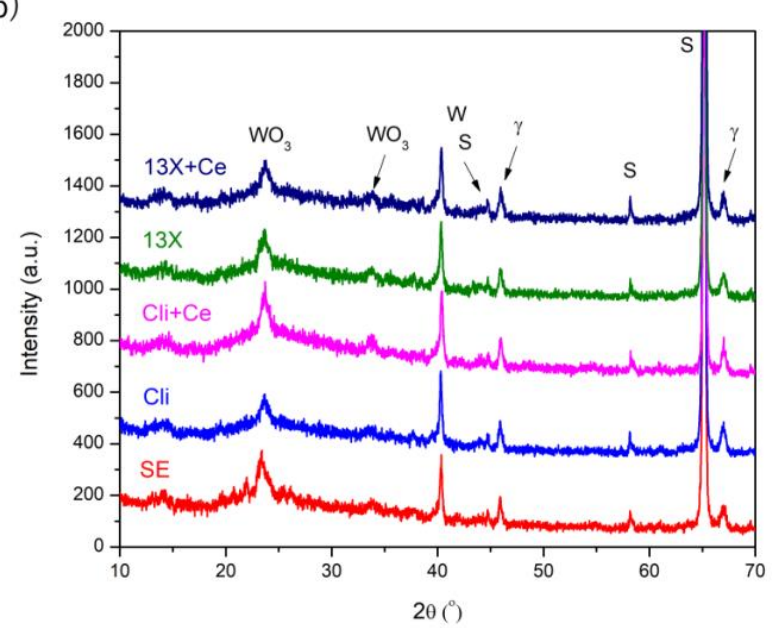

Figure 2. (a) XRD patterns of oxide coatings on $\mathrm{Al}$ containing clinoptilolite obtained for various $\mathrm{PEO}$ processing times. (b) XRD patterns of oxide coatings on $\mathrm{Al}$ containing different zeolites at 15 min of $\mathrm{PEO}\left(\gamma\right.$ represents $\gamma-\mathrm{Al}_{2} \mathrm{O}_{3}$, while $\mathrm{S}$ represents $\mathrm{Al}$ substrate).

At 5 min into the PEO process (Figure 2a), pronounced XRD maxima originating from the $\mathrm{Al}$ substrate and low maxima originating from $\gamma-\mathrm{Al}_{2} \mathrm{O}_{3}$ (denoted as $\mathrm{S}$ and $\gamma$, respectively) were detected. With extended PEO processing time, a $\mathrm{WO}_{3}$ crystalline phase gradually appeared while the diffraction maxima originating from $\mathrm{Al}$ substrate decreased as a result of increasing coating thickness, along with more prominent $\gamma-\mathrm{Al}_{2} \mathrm{O}_{3}$ phase diffraction maxima, indicating a higher level of crystallization of the oxide coating.

During the anodization, coating growth is a result of opposite migration assisted by the high electric field of the aluminum ionized at the aluminum-oxide interface and of anions formed at the oxide-electrolyte interface as a result of adsorbed water dissociation. The main chemical reaction at the aluminum-oxide interface are:

$$
\begin{gathered}
2 \mathrm{Al}+3 \mathrm{O}_{\text {solid }}^{2-} \rightarrow \mathrm{Al}_{2} \mathrm{O}_{3}+6 \mathrm{e}^{-} \\
\mathrm{Al} \rightarrow \mathrm{Al}_{\text {solid }}^{3+}+3 \mathrm{e}^{-}
\end{gathered}
$$

At the oxide-electrolyte interface the main chemical reaction is:

$$
2 \mathrm{Al}_{\text {solid }}^{3+}+9 \mathrm{H}_{2} \mathrm{O} \rightarrow \mathrm{Al}_{2} \mathrm{O}_{3}+6 \mathrm{H}_{3} \mathrm{O}^{+}
$$

Incorporation of tungsten in the PEO coatings is possible via the following chemical reactions [25]:

$$
\begin{gathered}
2 \mathrm{Al}_{\text {solid }}^{3+}+\mathrm{WO}_{4}^{2-} \text { electrolyte } \\
+6 \mathrm{H}_{2} \mathrm{O} \rightarrow \mathrm{WO}_{3}+\mathrm{Al}_{2} \mathrm{O}_{3}+4 \mathrm{H}_{3} \mathrm{O}^{+} \\
\mathrm{WO}_{4}^{2-} \text { electrolyte } \\
+2 \mathrm{H}_{3} \mathrm{O}^{+} \rightarrow \mathrm{WO}_{3}+3 \mathrm{H}_{2} \mathrm{O}
\end{gathered}
$$

During anodization, some of the $\mathrm{WO}_{4}{ }^{2-}$ anions are drawn from the electrolyte into the discharge channels by a strong electric field, where they are decomposed:

$$
2 \mathrm{WO}_{4}^{2-} \text { electrolyte }-4 \mathrm{e}^{-} \rightarrow 2 \mathrm{WO}_{3}+\mathrm{O}_{2} \uparrow
$$

Since $\mathrm{Al}$ is plentiful in the microdischarge channels, $\mathrm{WO}_{3}$ can react with $\mathrm{Al}$ under high-temperature conditions:

$$
\mathrm{WO}_{3}+2 \mathrm{Al} \rightarrow \mathrm{Al}_{2} \mathrm{O}_{3}+\mathrm{W}
$$


The latter reaction represents how metallic $\mathrm{W}$ could be incorporated into a PEO oxide coating, as its diffraction maxima increase with prolonged PEO processing time (Figure 2a) [25].

Diffraction maxima originating from pure and Ce-exchanged zeolites are not present in the XRD patterns in Figure 2a,b, most probably as a result of their low concentration or good dispersion in the obtained PEO coatings. Interestingly, the amorphous phase that was detected for a similar system was not present in the obtained coatings [22].

It should also be pointed out that $\alpha-\mathrm{Al}_{2} \mathrm{O}_{3}$ diffraction maxima were not observed, although they typically appear in a similar experimental setup [21], which suggests a significant influence of the PEO electrolyte on the phase compositions of oxide coatings [13].

Figure 3 shows top-view SEM micrographs of coatings created during a $10 \mathrm{~min}$ PEO process performed in supporting electrolytes without and with the addition of $1 \mathrm{~g} / \mathrm{L}$ of pure and Ce-exchanged clinoptilolite and $13 \mathrm{X}$ zeolites. It is observable that all prepared samples have very similar surface morphologies. The obtained coatings show typical characteristics resulting from PEO processing, which entails surfaces ornamented with a number of microdischarge channels of various forms and diameters, areas shaped by the rapid cooling of molten material ejected from them, and cracks. These porous surfaces could be useful for luminescence and photocatalytic applications, as they ensure a well-developed and spacious surface area.
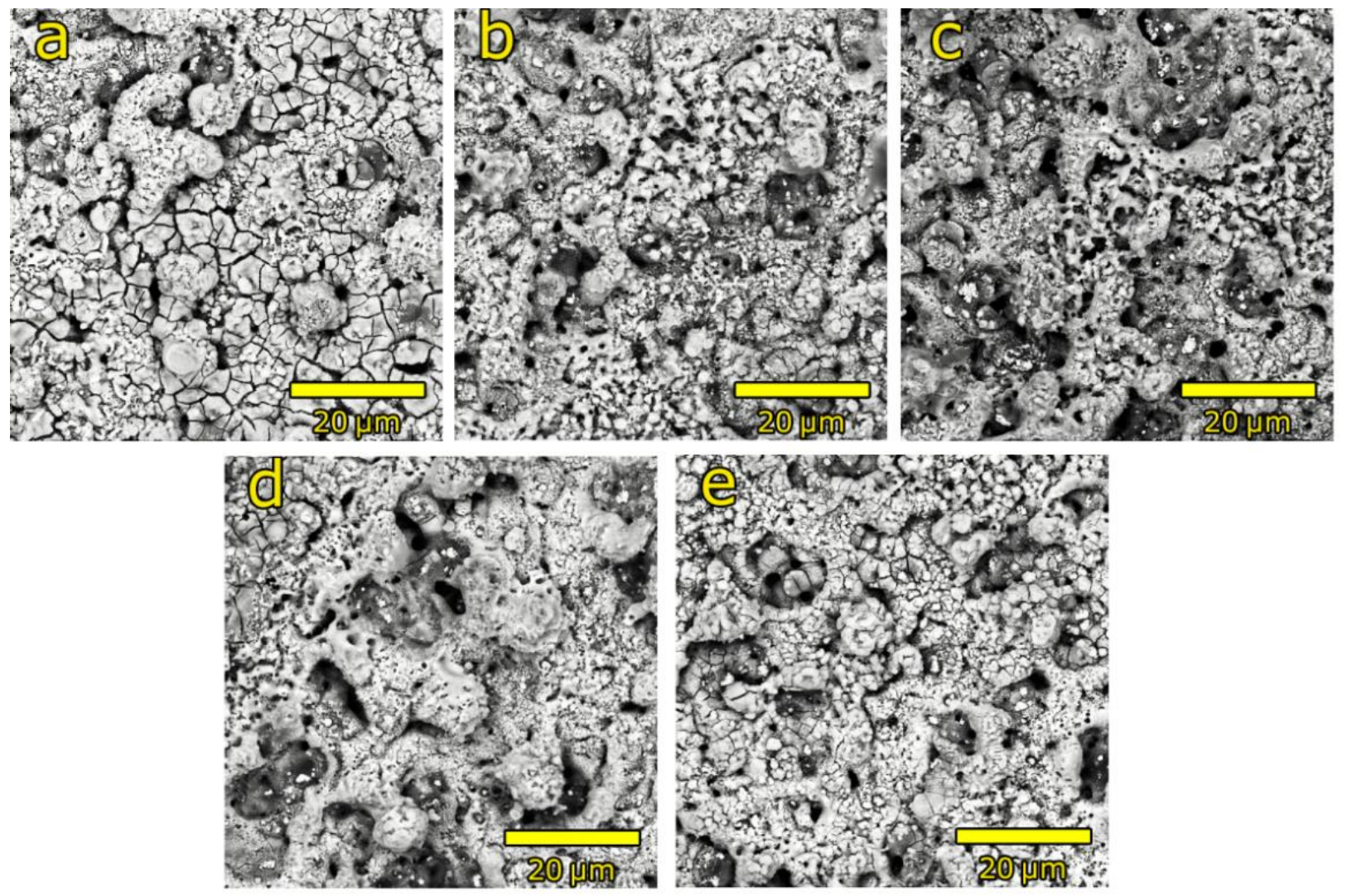

Figure 3. Top surface morphologies of coatings obtained during $10 \mathrm{~min}$ PEO in supporting electrolyte (a) and with the addition of (b) clinoptilolite, (c) Ce-exchanged clinoptilolite, (d) 13X, or (e) Ce-exchanged 13X.

The evolution of the surface morphologies with PEO processing time for coatings obtained in supporting electrolyte with the addition of $1 \mathrm{~g} / \mathrm{L}$ of Ce-loaded clinoptilolite is shown in Figure 4. It can be observed that with prolonged PEO processing time, the number of the microdischarging channels decreases but the size of microdischarge channels increases, resulting in a smaller number of larger pores. 


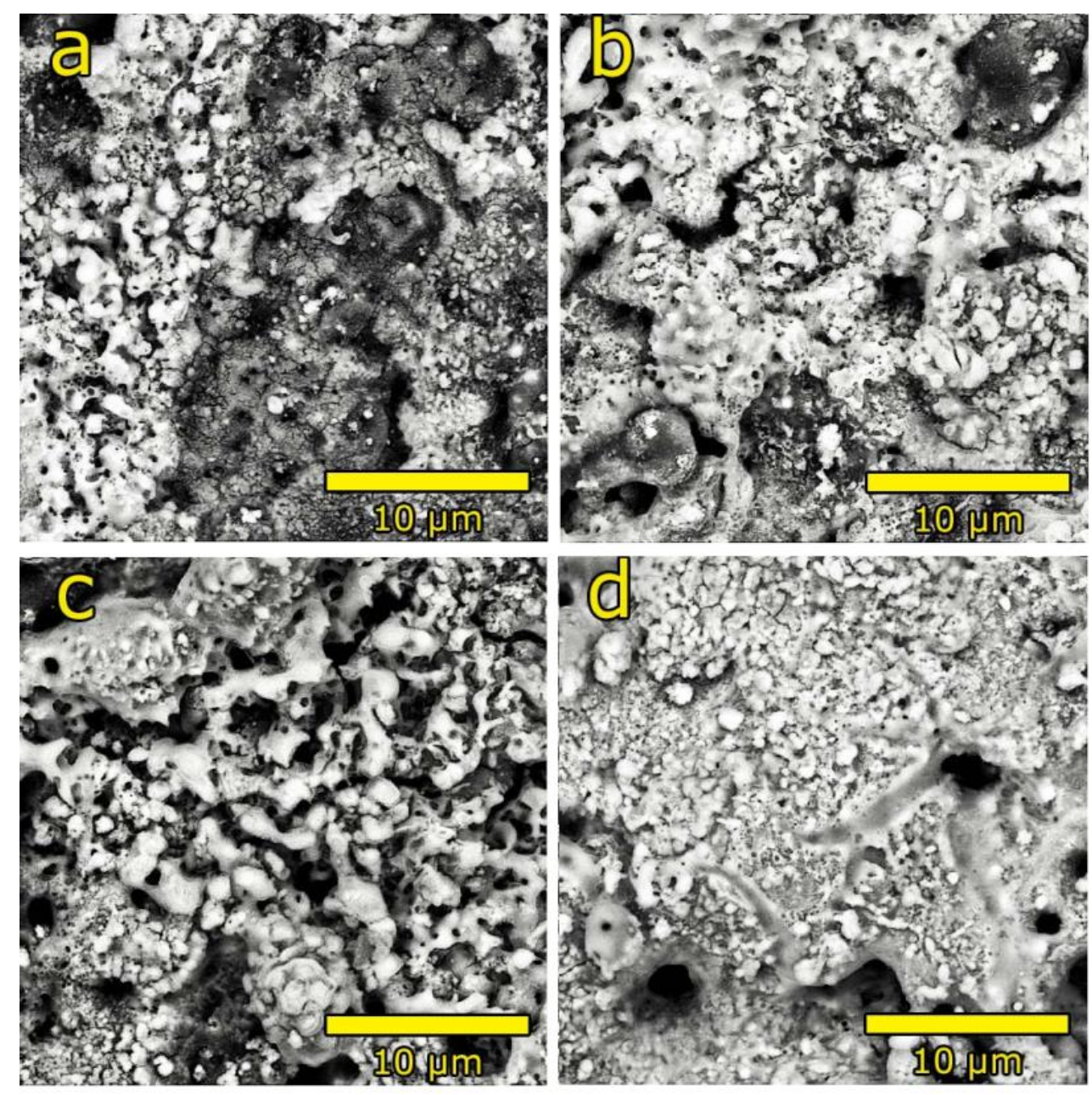

Figure 4. SEM micrographs of coatings obtained in Ce-enriched clinoptilolite containing electrolytes at different PEO process durations: (a) $5 \mathrm{~min}$; (b) $7 \mathrm{~min}$; (c) $10 \mathrm{~min}$; (d) $15 \mathrm{~min}$.

From Figures 3 and 4, it is clear that the introduction of zeolites has an effect on the microstructure and morphology of PEO coatings. The SEM image of the PEO coating obtained in electrolytes without the addition of zeolites (Figure 3a) shows a number of cracks which appear as a result of rapid cooling of the molten material in contact with electrolytes and accumulated stress $[27,28]$. All defects on the PEO coating can be considered as routes for particles (in this case zeolite particles) to propagate into the internal part of the coating, making it less porous [13]. Generally speaking, the addition of particles into electrolytes used for PEO processing acts as a sealant, making the obtained PEO coatings denser and thicker. The transfer of zeolite particles from electrolytes towards the anode is possible due to the strong electric field inherent to plasma electrolytic oxidation, which can be further promoted by hydration and charging of nanoparticles or hydrodynamic effects caused by surface discharge heating and convection [28].

The cross-sections of obtained composite PEO coatings (Figure 5) show increased in thickness for all obtained coatings throughout the PEO process; nevertheless, the addition of zeolite particles resulted in the formation of thicker and less porous PEO layers than those obtained in the supporting electrolyte (Table 2). The porosity of the obtained coatings was highest after $10 \mathrm{~min}$ of PEO and slightly decreased after that point, while the thickest PEO layer was around $7 \mu \mathrm{m}$ thick. 

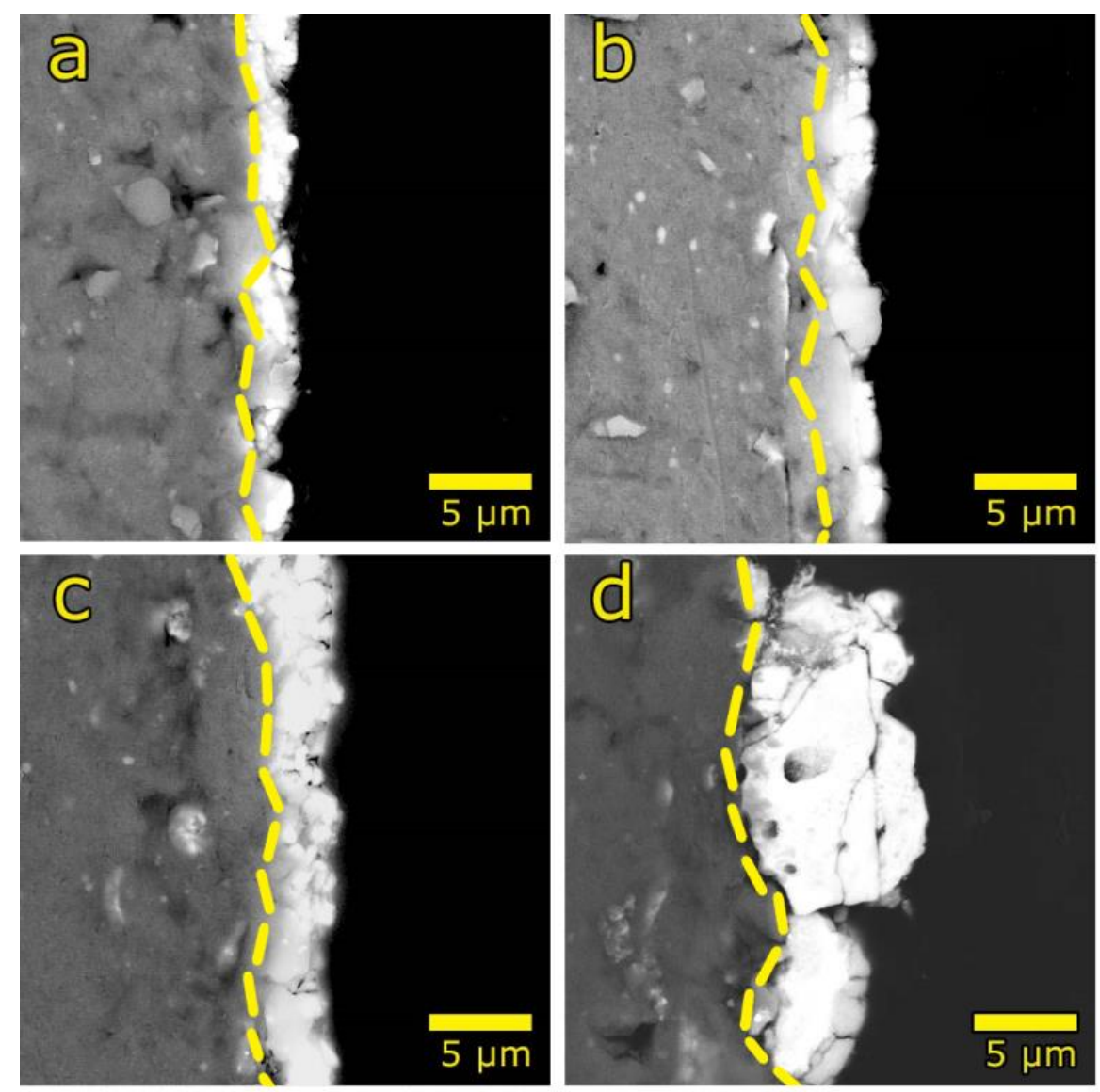

Figure 5. Cross-sections of coatings obtained in Ce-enriched clinoptilolite containing electrolytes after different PEO process durations: (a) $5 \mathrm{~min}$; (b) $7 \mathrm{~min}$; (c) $10 \mathrm{~min}$; (d) $15 \mathrm{~min}$.

Table 2. Porosity percentages and thicknesses of coatings obtained in different electrolytes and with different PEO processing times.

\begin{tabular}{|c|c|c|c|}
\hline Sample & PEO Time (min) & Porosity (\%) & Thickness $(\mu \mathrm{m})$ \\
\hline \multirow{4}{*}{ Cli } & 5 & 13.04 & 2.57 \\
\hline & 7 & 11.67 & 3.52 \\
\hline & 10 & 9.83 & 4.36 \\
\hline & 15 & 10 & 5.91 \\
\hline \multirow{4}{*}{$\mathrm{Cli}+\mathrm{Ce}$} & 5 & 11.85 & 2.33 \\
\hline & 7 & 9.11 & 2.86 \\
\hline & 10 & 7.27 & 3.1 \\
\hline & 15 & 8.77 & 7.16 \\
\hline \multirow{4}{*}{$13 X$} & 5 & 10.67 & 1.97 \\
\hline & 7 & 9.45 & 2.57 \\
\hline & 10 & 9.17 & 3.52 \\
\hline & 15 & 8.98 & 6.03 \\
\hline \multirow{4}{*}{$13 X+C e$} & 5 & 10.41 & 2.92 \\
\hline & 7 & 8.29 & 3.58 \\
\hline & 10 & 6.91 & 4.06 \\
\hline & 15 & 7.58 & 5.97 \\
\hline \multirow{4}{*}{ SE } & 5 & 25.09 & / \\
\hline & 7 & 19.45 & 2.51 \\
\hline & 10 & 15.54 & 2.68 \\
\hline & 15 & 17.11 & / \\
\hline
\end{tabular}


The surface morphology evolution of the PEO coatings represented through threedimensional AFM images for different processing times in electrolytes with and without Ce-exchanged clinoptilolite is shown in Figures 6 and 7.

(a)

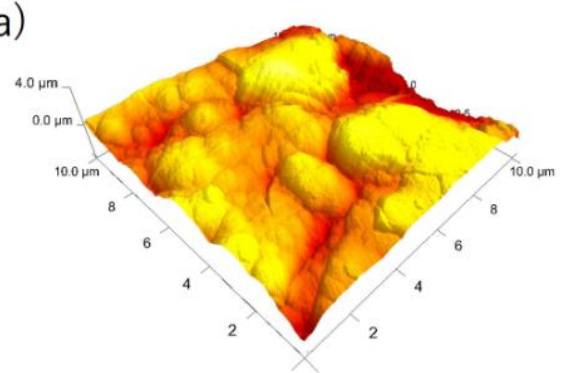

(c)

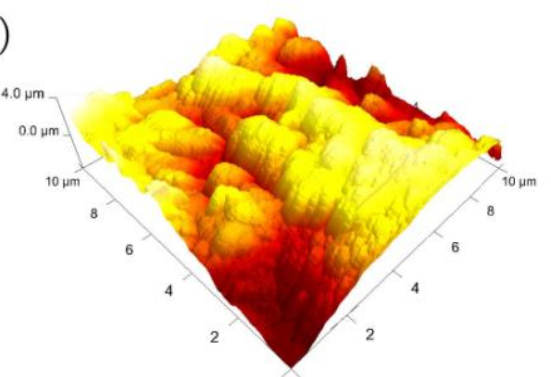

(b)

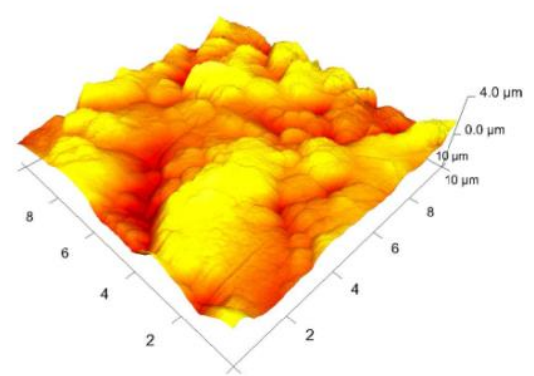

(d)

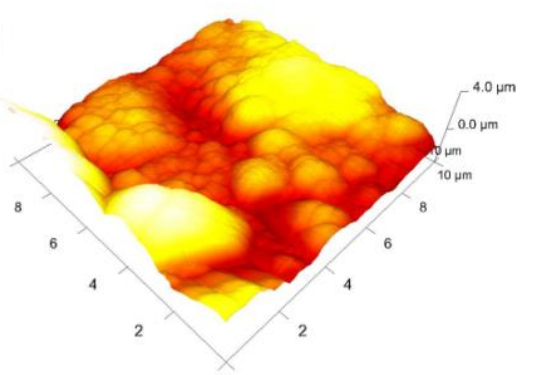

Figure 6. Three-dimensional AFM images of oxide coatings formed in supporting electrolytes at various stages of the $P E O$ process: (a) $5 \mathrm{~min}$; (b) $7 \mathrm{~min}$; (c) $10 \mathrm{~min}$; (d) $15 \mathrm{~min}$.

(a)

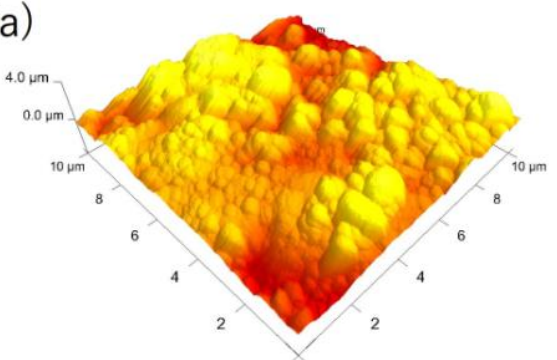

(c)

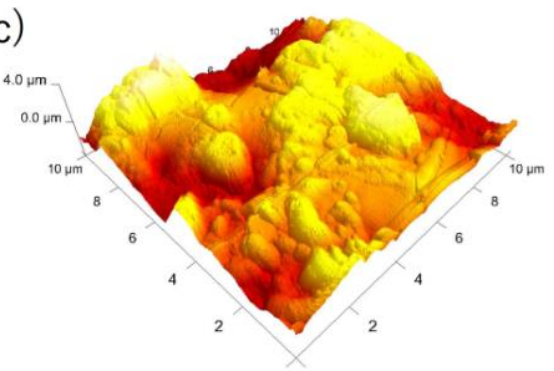

(b)

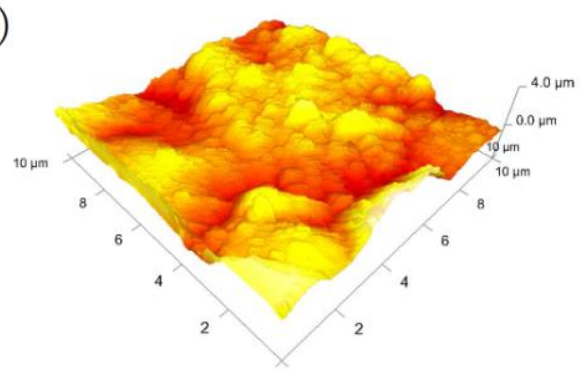

(d)

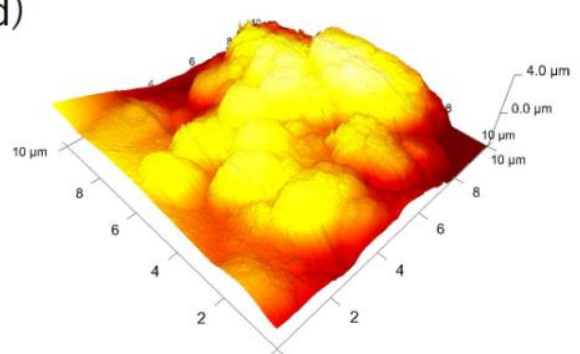

Figure 7. Three-dimensional AFM images of oxide coatings formed in supporting electrolytes with Ce-exchanged clinoptilolite at various stages of the PEO process: (a) $5 \mathrm{~min}$; (b) $7 \mathrm{~min}$; (c) $10 \mathrm{~min}$; (d) $15 \mathrm{~min}$.

Both Figures 6 and 7 show a growing presence of non-uniformities for longer PEO processing times, which is in agreement with the fact that with prolonged $\mathrm{PEO}$, the number of microdischarges decreases while their size increases $[10,28]$. Thicker coatings have higher surface roughness because in the initial stage of PEO the discharge channels are well distributed and oxide coatings exhibit lower surface roughness. As the number of discharge channels decreases with time of PEO, non-uniformities in the oxide coatings appear, causing 
an increase in surface roughness. This increase of the surface roughness is even more pronounced with addition of particles, i.e., Ce-exchanged clinoptilolite (Figure 8).

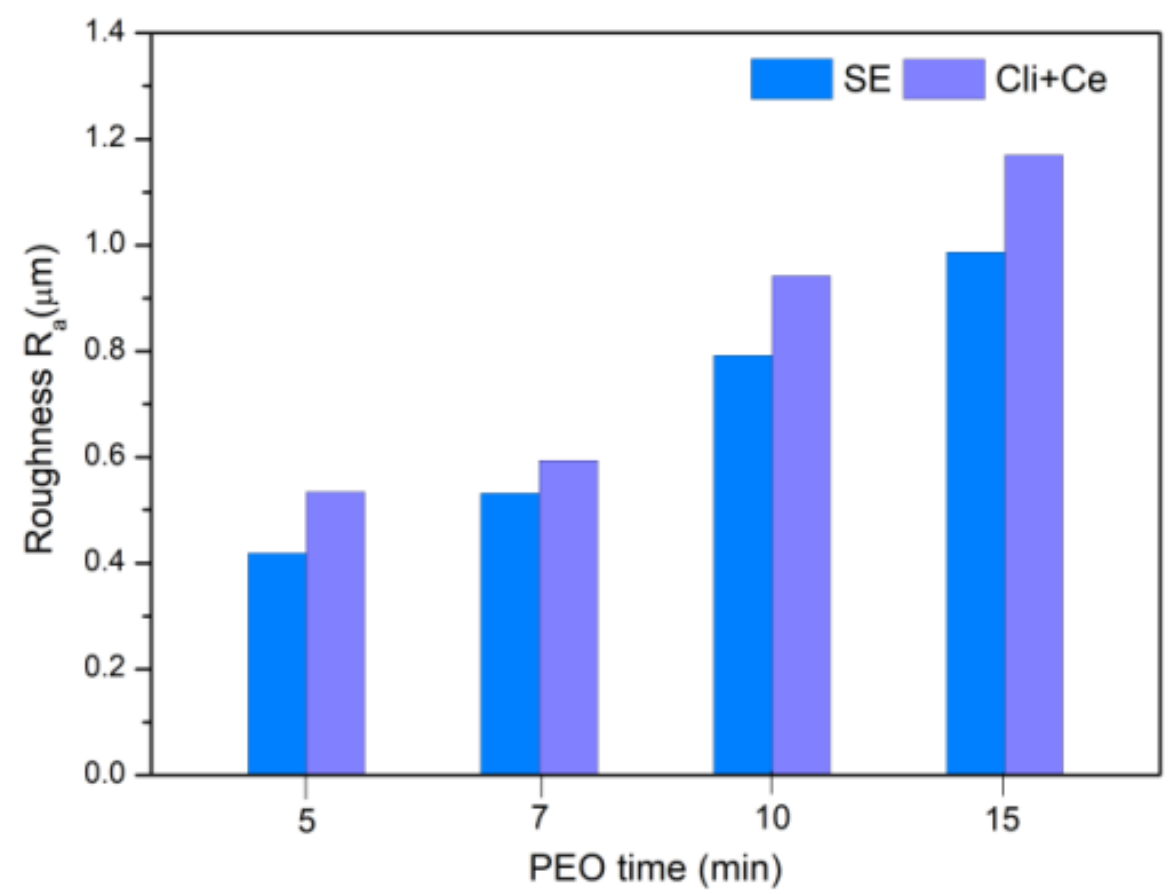

Figure 8. Surface roughness $\mathrm{R}_{\mathrm{a}}$ for PEO coatings obtained with different processing times in electrolytes with and without Ce-exchanged clinoptilolite.

The results of the EDS area analysis of surface coatings obtained in electrolytecontaining, Ce-loaded clinoptilolite with different PEO processing times are presented in Table 3.

Table 3. EDS analysis of Cli + Ce coatings with various PEO processing times.

\begin{tabular}{ccccc}
\hline & \multicolumn{4}{c}{ PEO Time (min) } \\
\hline \multirow{2}{*}{ Element } & $\mathbf{5}$ & $\mathbf{7}$ & $\mathbf{1 0}$ & $\mathbf{1 5}$ \\
\cline { 2 - 5 } & \multicolumn{4}{c}{ Weight Percent $\mathbf{( w \mathbf { ~ } \mathbf { 0 } )}$} \\
\hline $\mathrm{Al}$ & 29.26 & 21.94 & 20.31 & 13.91 \\
$\mathrm{~W}$ & 3.59 & 5.43 & 7.69 & 11.03 \\
$\mathrm{O}$ & 62.93 & 64.73 & 65.84 & 67.92 \\
$\mathrm{C}$ & 4.07 & 7.72 & 6.16 & 6.82 \\
$\mathrm{Na}$ & 0.15 & 0.18 & - & 0.32 \\
\hline
\end{tabular}

The main elements of the coatings were $\mathrm{Al}, \mathrm{W}$, and $\mathrm{O}$, including $\mathrm{C}$ and $\mathrm{Na}$. Detailed EDS analysis showed increases in the concentrations of $\mathrm{O}$ and $\mathrm{W}$ and a decrease in the concentration of $\mathrm{Al}$ with prolonged $\mathrm{PEO}$ time. The presence of $\mathrm{C}$ is related to utilization of the carbon tape used for mounting the samples onto the holder and from the vacuum system; however, we were not able to detect some of the main elements of zeolites (for example $\mathrm{Si}$ ) or Ce through top-view surface measurements, so we performed cross-sectional EDS line analyses of the obtained coatings (Figure 9). This form of investigation confirmed the presence of $\mathrm{Si}$ and Ce in the coatings, although suggested that the concentration of $\mathrm{Ce}$ was very close to the detection limit of the used EDS system. 
(a)

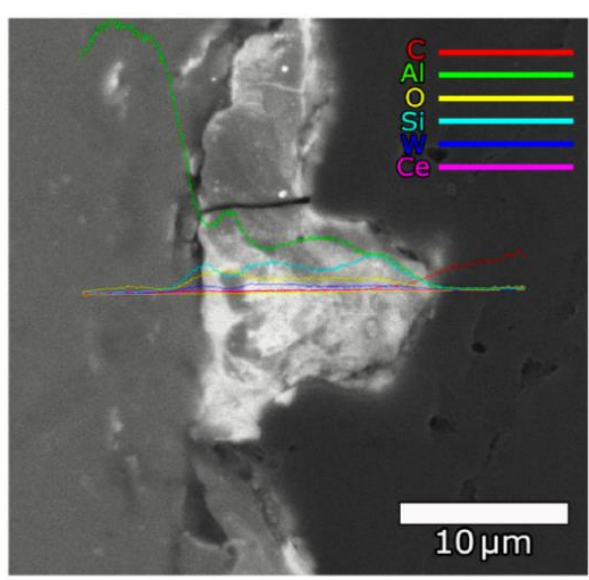

(b)
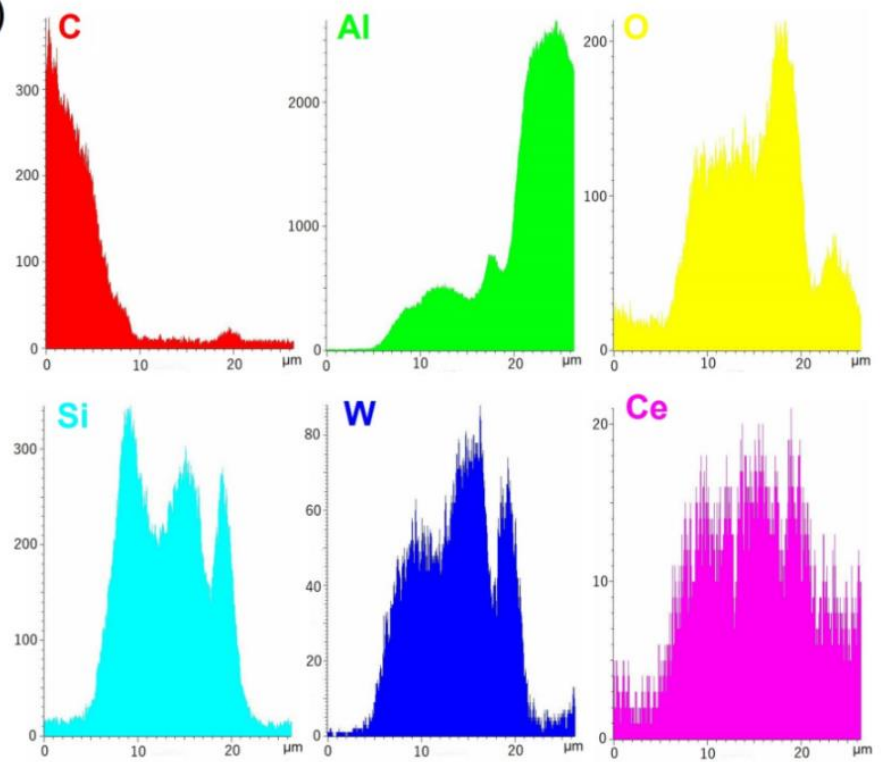

Figure 9. (a) SEM micrograph of a Cli + Ce coating obtained through a 15 min PEO process with EDS analysis. (b) Representation of each element's presence in the coating.

Since we were not able to quantify the Ce contents in obtained coatings, we performed a set of photoluminescence measurements because Ce-containing species feature pronounced emissions when excited by UV radiation [29]. PL emission spectra of PEO coatings with immobilized Ce-loaded clinoptilolite particles are shown in Figure 10. The total PL intensity of these coatings is the sum of $\mathrm{PL}$ originating from $\mathrm{Al}_{2} \mathrm{O}_{3}$ species and $\mathrm{Ce}^{3+}$ ions. Obviously, the main contribution to PL emission spectra is from $\mathrm{Ce}^{3+}$ ions, as they exhibit an intense emission band at around 320-330 nm due to the $4 \mathrm{f}^{7} \rightarrow 4 \mathrm{f}^{6} 5 \mathrm{~d}^{1}$ transition [30], which is especially visible when compared to the emission of the pure $\mathrm{Al}_{2} \mathrm{O}_{3}$ coating formed in supporting electrolytes without the addition of pure or Ce-exchanged zeolites. This contribution increases with prolonged PEO processing time, suggesting an increase of Ce concentrations in the obtained coatings.

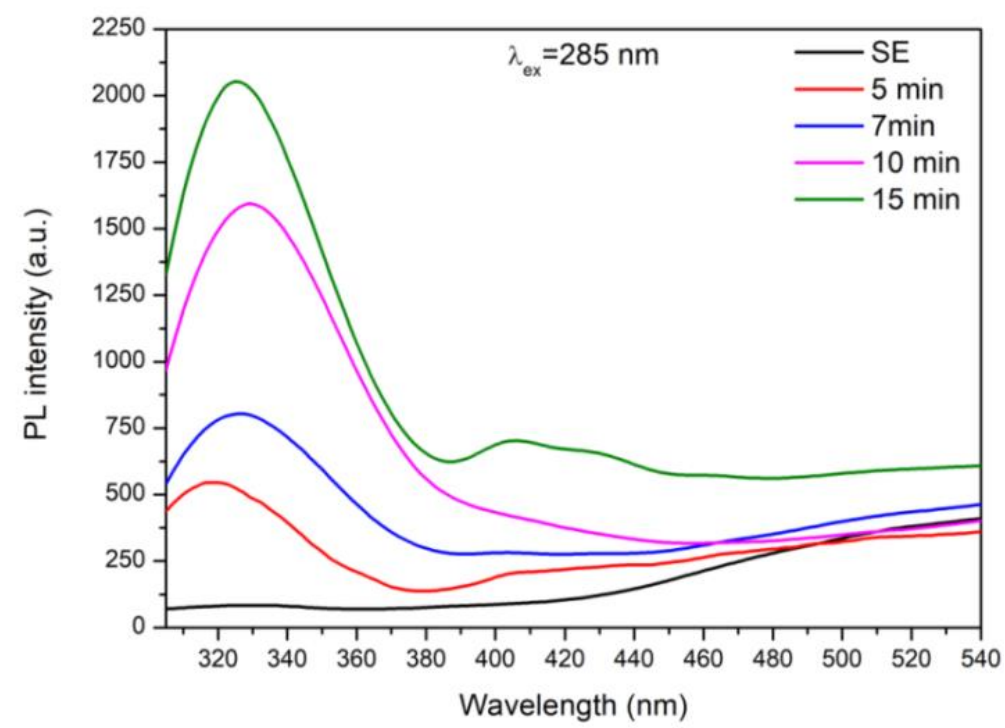

Figure 10. Photoluminescence emission spectra of PEO coatings formed on Al substrate in the supporting electrolyte and with the addition of Ce-exchanged clinoptilolite particles. 


\subsection{Photocatalytic Activity of PEO Coatings}

The photocatalytic activity levels of PEO coatings formed in the supporting electrolyte and with immobilized pure and Ce-enriched zeolites are shown in Figure 11a. $\mathrm{C}_{0}$ is the initial concentration of $\mathrm{MO}$ and $\mathrm{C}$ is the concentration after time $\mathrm{t}$.

(a)

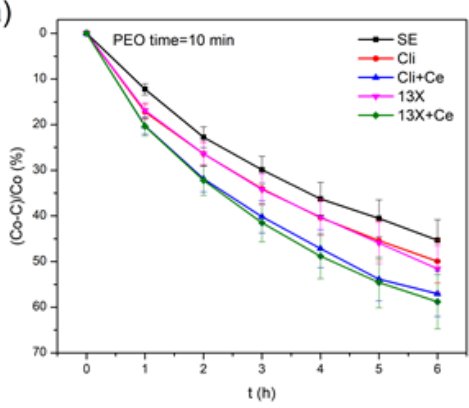

(b)

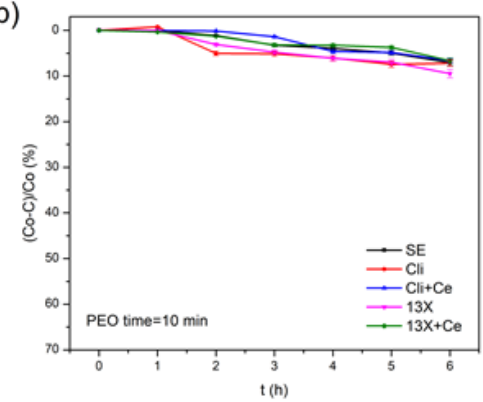

(c)

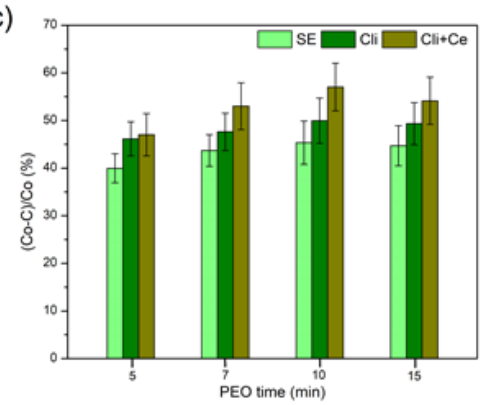

Figure 11. (a) Photocatalytic activity levels of oxide coatings after 10 min compared to the beginning of PEO. (b) Removal of $\mathrm{MO}$ in the dark in the presence of oxide coatings containing zeolites. (c) Photocatalytic activity levels of the coatings after $6 \mathrm{~h}$ of irradiation.

The irradiation of photocatalysts leads to the production of electron-hole pairs. For the efficient degradation of methyl orange, inhibition of electron-hole pair recombination is required. The photogenerated electrons easily migrate from valence to conduction bands and positive holes are formed in the valence band. The electrons from the conductive band can react with $\mathrm{O}_{2}$, forming an anion radical superoxide $\mathrm{O}_{2}{ }^{\bullet-}$. Further reaction can lead to the formation of hydrogen peroxide, which leads to the formation of ${ }^{\bullet} \mathrm{OH}$ radicals. In addition, the holes react with $\mathrm{H}_{2} \mathrm{O}$ to generate ${ }^{\bullet} \mathrm{OH}$ radicals [22,31]. Oxidative degradation of azo dyes generally occurs via the subsequent attacks of $\bullet \mathrm{OH}$ radicals [32].

The respectable levels of photocatalytic activity observed for all prepared coatings were most likely the result of the applied continuous DC electrical regime and the surface morphology, which entails a lower level of homogeneity, higher thickness of the porous layers, and higher porosity and roughness $[33,34]$. It is apparent that the highest efficiency of the MO degradation for oxide coatings formed on $\mathrm{Al}$ was obtained by adding Ce-loaded $13 \mathrm{X}$ zeolite to the supporting electrolyte. In general, it was revealed that adding Ce to zeolites raises the photocatalytic activity of the oxides by about $10 \%$ for both clinoptilolite and 13X zeolites; however, it is worth noting that the photocatalytic activity levels of clinoptilolite and 13X samples were the same (within the error margin), allowing us to focus on clinoptilolite as an inexpensive, abundant, and naturally occurring zeolite (Figure 11c).

In order to determine whether adsorption of methyl orange occurred on photocatalysts, adsorption experiments were conducted, i.e., measurement of changes in methyl orange concentrations when samples were not illuminated (Figure 11b). It was obvious that the adsorption was quite small compared to the photoactivity, i.e., the increase in $\mathrm{MO}$ photodegradation as the result of photocatalytic reactions in the presence of zeolites immobilized on aluminum support by plasma electrolytic oxidation.

Further inspection of $\mathrm{MO}$ photodegradation results for composite coatings containing clinoptilolite showed that the photocatalytic activity increased with PEO treatment time until $10 \mathrm{~min}$, after which a moderate decline is observed. This may have been related to an interplay between the surface morphology and the concentration of Ce-containing active sites accessible to irradiation, which are both strongly dependent on PEO treatment time $[10,13,27,35]$.

\subsection{Potentiodynamic Polarization of the Coatings}

Figure 12 shows potentiodynamic polarization curves of bare $\mathrm{Al}$ and coatings obtained after $10 \mathrm{~min}$ and $15 \mathrm{~min}$ of PEO processing in electrolytes containing the pure and Ceenriched zeolites clinoptilolite and 13X. Corrosion current densities were determined using Tafel extrapolation only for PEO coatings obtained after $10 \mathrm{~min}$ (Table 4) and $15 \mathrm{~min}$ 
(Table 5) of processing, since we were unable to examine the corrosion rates for coatings with lower processing times. Coatings formed after 5 and $7 \mathrm{~min}$ of PEO processing showed noticeable OCP instability. This was probably due to the relatively high porosity of these coatings and the fact that the electrolytes can easily penetrate the coating and reach the substrate, while coatings treated for 10 and 15 min achieved higher levels of thickness and lower porosity, preventing the access of the electrolytes towards the substrate. The analyzed coatings show lower corrosion rates than bare $\mathrm{Al}$ by approximately two and one order of magnitude after 10 and 15 min of PEO processing, respectively. Clearly, PEO coatings obtained after $10 \mathrm{~min}$ of PEO processing are more successful in corrosion protection due to their lower porosity. The lowest corrosion current density values were observed for $13 \mathrm{X}+\mathrm{Ce}$ samples for both processing times. Their calculated values were lower than those for the samples without $\mathrm{Ce}$, suggesting that the addition of Ce improves the corrosion stability [15]. On the other hand, this effect was not very pronounced due to the very low and in some cases quantitatively undetectable concentrations of $\mathrm{Ce}$ in the coatings.

(a)

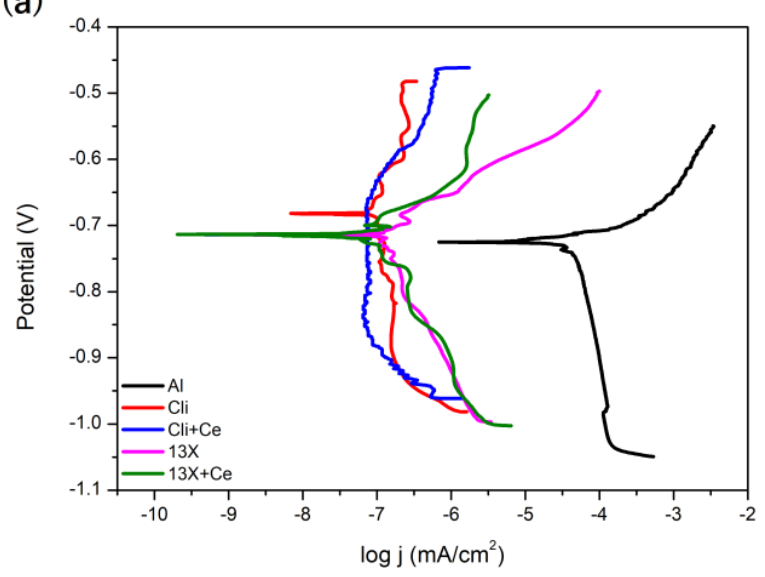

(b)

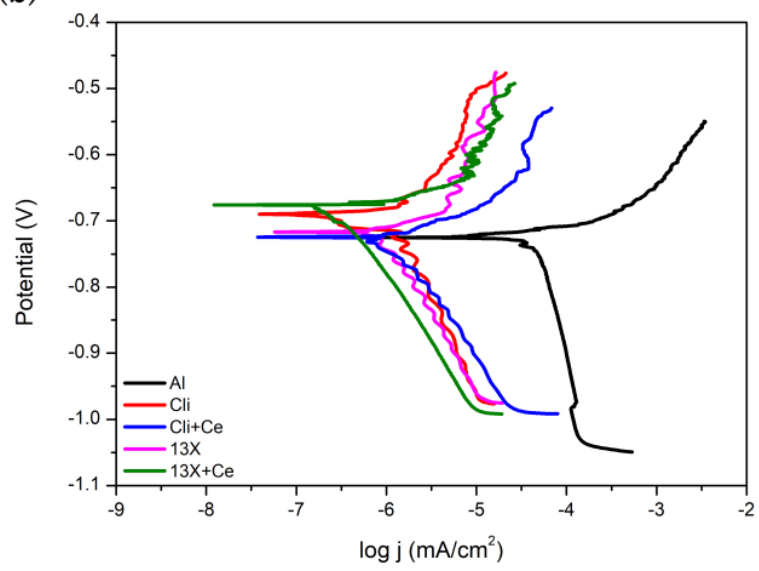

Figure 12. Tafel curves of PEO coatings obtained after the PEO processing: (a) $10 \mathrm{~min}$; (b) $15 \mathrm{~min}$.

Table 4. Corrosion parameters for coatings obtained after $10 \mathrm{~min}$ of PEO processing and $1 \mathrm{~h}$ of exposure to $3.5 \% \mathrm{NaCl}$.

\begin{tabular}{ccc}
\hline Sample & $\mathbf{j}_{\text {corr }}\left(\boldsymbol{\mu} \mathbf{A} \mathbf{c m}^{-2}\right)$ & $\mathbf{E}_{\text {corr }}(\mathbf{V})$ \\
\hline $\mathrm{Al}$ & 0.959 & -0.816 \\
$\mathrm{Cli}$ & 0.0093 & -0.682 \\
$\mathrm{Cli}+\mathrm{Ce}$ & 0.0056 & -0.713 \\
$13 \mathrm{X}$ & 0.0126 & -0.714 \\
$13 \mathrm{X}+\mathrm{Ce}$ & 0.0046 & -0.719 \\
\hline
\end{tabular}

Table 5. Corrosion parameters for coatings obtained after $15 \mathrm{~min}$ of PEO processing and $1 \mathrm{~h}$ of exposure to $3.5 \% \mathrm{NaCl}$.

\begin{tabular}{ccc}
\hline Sample & $\mathbf{j}_{\text {corr }}\left(\boldsymbol{\mu} \mathbf{A} \mathbf{~ c m}^{-2}\right)$ & $\mathbf{E}_{\text {corr }} \mathbf{( V )}$ \\
\hline $\mathrm{Al}$ & 0.959 & -0.816 \\
$\mathrm{Cli}$ & 0.0456 & -0.682 \\
$\mathrm{Cli}+\mathrm{Ce}$ & 0.0137 & -0.713 \\
$13 \mathrm{X}$ & 0.0473 & -0.714 \\
$13 \mathrm{X}+\mathrm{Ce}$ & 0.0061 & -0.719 \\
\hline
\end{tabular}

Nonetheless, the corrosion current density values for $13 \mathrm{X}+\mathrm{Ce}$ and $\mathrm{Cli}+\mathrm{Ce}$ were very close, which also applied to $13 \mathrm{X}$ and Cli samples (averaged results for three separately prepared samples are presented), making natural clinoptilolite as good (or as bad) as synthetic 13X for corrosion protection applications. 
It is also worth mentioning that the results of the Tafel extrapolation should be viewed with caution, since it is a fast technique that provides immediate and unaveraged results for longer periods of immersion [36].

\section{Conclusions}

Oxide coatings with immobilized pure and Ce-exchanged zeolites were deposited on aluminum support from tungstate-based aqueous electrolytes using DC PEO processing. The obtained coatings were characterized for their morphologies, chemical and phase compositions, levels of photoluminescence and photocatalytic activity, and corrosion properties.

The obtained coatings were mostly crystalline containing $\gamma$-alumina, $\mathrm{WO}_{3}$, and metallic tungsten. The surface morphologies of the obtained coatings were independent of the used zeolite, but strongly depended on the PEO processing time; the roughness of all coatings increased with PEO time, while the porosity decreases with PEO processing time as a result of microdischarge coalescence or growth. All coatings contained elements originating from the substrate and from the electrolyte. The cerium concentrations were very low in all coatings, as revealed by EDS. We used PL as a tool to qualitatively probe the Ce contents in the coatings and showed that it increases with prolonged PEO processing time.

The highest photocatalytic activity was observed for coatings with immobilized Ceexchanged zeolite processed for $10 \mathrm{~min}$. Coatings containing zeolites with Ce showed higher photoactivity than those with immobilized pure zeolites. Coatings with both Ceexchanged clinoptilolite and 13X zeolite showed increased photoactivity up to $10 \mathrm{~min}$ of processing, which dropped with prolonged PEO processing time. This behavior was related to Ce content and coating morphology. The effect of Ce was not as strongly, pronounced on the anti-corrosion properties due to its low concentration in the coatings although it was still visible. Potentiodynamic polarization experiments suggested that coatings containing Ce-exchanged 13X zeolite processed for $10 \mathrm{~min}$ had the lowest corrosion current density values.

Author Contributions: K.M., investigation, data curation, visualization. U.L., investigation, data curation. S.S. (Srna Stojanović). Investigation. L.D.-V., conceptualization, writing. S.S. (Stevan Stojadinović), methodology. R.V., conceptualization, supervision, writing-reviewing and editing. This manuscript was written with contributions from all authors. All authors have read and agreed to the published version of the manuscript.

Funding: This work was supported by the Ministry of Education, Science, and Technological Development of the Republic of Serbia (S.S. and L.D.-V. acknowledge the financial support from MESTD contract number: 451-03-9/2021-14/200146) and by the European Union Horizon 2020 research and innovation program under the Marie Sklodowska-Curie grant agreement no. 823942 (FUNCOAT).

Institutional Review Board Statement: Not applicable.

Informed Consent Statement: Not applicable.

Data Availability Statement: Not applicable.

Conflicts of Interest: The authors declare that they have no known competing financial interests or personal relationships that could have appeared to influence the results reported in this paper.

\section{References}

1. Kumar, S.G.; Rao, K.S.R.K. Comparison of modification strategies towards enhanced charge carrier separation and photocatalytic degradation activity of metal oxide semiconductors $\left(\mathrm{TiO}_{2}, \mathrm{WO}_{3}\right.$ and $\left.\mathrm{ZnO}\right)$. Appl. Surf. Sci. 2017, 391, 124-148. [CrossRef]

2. Moreira, N.F.F.; Sampaio, M.J.; Ribeiro, A.R.; Silva, C.G.; Faria, J.L.; Silva, A.M.T. Metal-free g-C3N4 photocatalysis of organic micropollutants in urban wastewater under visible light. Appl. Catal. B Environ. 2019, 248, 184-192. [CrossRef]

3. Tao, W.; Wang, M.; Ali, R.; Nie, S.; Zeng, Q.; Yang, R.; Lau, W.-M.; He, L.; Tang, H.; Jian, X. Multi-layered porous hierarchical $\mathrm{TiO}_{2} / \mathrm{g}-\mathrm{C}_{3} \mathrm{~N}_{4}$ hybrid coating for enhanced visible light photocatalysis. Appl. Surf. Sci. 2019, 495, 143345. [CrossRef]

4. Ighadon, A.O.; Fitzpatrick, P. Heterogeneous photocatalysis: Recent advances and applications. Catalysts 2013, 3, 189-218. [CrossRef] 
5. Kanakkillam, S.; Shaji, S.; Krishnan, B.; Vazquez-Rodriguez, S.; Martinez, J.A.A.; Palma, M.I.M.; Avellaneda, D.A. Nanoflakes of zinc oxide:cobalt oxide nanocomposites by pulsed laser fragmentation for visible light photocatalysis. Appl. Surf. Sci. 2020, 501, 144223. [CrossRef]

6. Dostanić, J.; Grbić, B.; Radić, N.; Stojadinović, S.; Vasilić, R.; Vuković, Z. Preparation and photocatalytic properties of TiO 2 -P25 film prepared by spray pyrolysis method. Appl. Surf. Sci. 2013, 274, 321-327. [CrossRef]

7. Stojadinovic, S.; Tadic, N.; Radic, N.; Grbic, B.; Vasilic, R. MgO/ZnO coatings formed on magnesium alloy AZ31 by plasma electrolytic oxidation: Structural, photoluminescence and photocatalytic investigation. Surf. Coat. Technol. 2017, 310, 98-105. [CrossRef]

8. Shan, A.Y.; Ghazi, T.I.M.; Rashid, S.A. Immobilization of titanium dioxide onto supporting materials in heterogeneous photocatalysis: A review. Appl. Catal. A Gen. 2010, 389, 1-8. [CrossRef]

9. Stojadinović, S.; Radić, N.; Tadić, N.; Vasilić, R.; Grbić, B. Enhanced ultraviolet light driven photocatalytic activity of ZnO particles incorporated by plasma electrolytic oxidation into $\mathrm{Al}_{2} \mathrm{O}_{3}$ coatings co-doped with Ce3 ${ }^{+}$. Opt. Mater. 2020, 101, 127-162. [CrossRef]

10. Clyne, T.W.; Troughton, S.C. A review of recent work on discharge characteristics during plasma electrolytic oxidation of various metals. Int. Mater. Rev. 2019, 64, 127-162. [CrossRef]

11. Tavares, M.M.; Vitoriano, J.O.; Silva, R.C.L.; Franco, A.R.; Souza, G.B.; Costa, J.A.P.; Alves-Junior, C. Effect of duty cycle and treatment time on electrolytic plasma oxidation of commercially pure Al samples. J. Mater. Res. Technol. 2019, 8, 2141-2147. [CrossRef]

12. Mojsilović, K.; Tadić, N.; Lačnjevac, U.; Stojadinović, S.; Vasilić, R. Characterization of Al-W oxide coatings on aluminum formed by pulsed direct current plasma electrolytic oxidation at ultra-low duty cycles. Surf. Coat. Technol. 2021, 411, 126982. [CrossRef]

13. Lu, X.; Mohedano, M.; Blawert, C.; Matykina, E.; Arrabal, R.; Kainer, K.U.; Zheludkevich, M.L. Plasma electrolytic oxidation coatings with particle additions-A review. Surf. Coat. Technol. 2016, 307, 1165-1182. [CrossRef]

14. Sels, B.; Kustov, L. Zeolites and Zeolite-Like Materials; Elsevier: Amsterdam, The Netherlands, 2016.

15. Dias, S.A.S.; Marques, A.; Lamaka, S.V.; Simões, A.; Diamantino, T.C. The role of Ce(III)-enriched zeolites on the corrosion protection of AA2024-T3. Electrochim. Acta 2013, 112, 549-556. [CrossRef]

16. Latha, P.; Karuthapandian, S. Novel, facile and swift technique for synthesis of $\mathrm{CeO}_{2}$ nanocubes immobilized on zeolite for removal of CR and MO dye. J. Clust. Sci. 2017, 28, 3265-3280. [CrossRef]

17. Alvarez-Aguiñaga, E.A.; Elizade-González, M.P.; Sabinas-Hernández, S.A. Unpredicted photocatalytic activity of clinoptilolitemodernite natural zeolite. RSC Adv. 2020, 10, 39251-39260. [CrossRef]

18. Ji, P.; Zhang, J.; Chen, F.; Anpo, M. Study of adsorption and degradation of acid orange 7 on the surface of $\mathrm{CeO}_{2}$ under visible light irradiation. Appl. Catal. B Environ. 2009, 85, 148-154. [CrossRef]

19. Li, H.; Zhang, W.; Liu, Y. HZSM-5 zeolite supported boron-doped $\mathrm{TiO}_{2}$ for photocatalytic degradation of ofloxacin. J. Mater. Res. Technol. 2020, 9, 2557-2567. [CrossRef]

20. Yhang, G.; Wu, L.; Tang, A.; Ding, X.; Jiang, B.; Atrens, A.; Pan, F. Smart epoxy coating containing zeolites loaded with Ce on a plasma electrolytic oxidation coating on Mg alloy AZ31 for active corrosion protection. Prog. Org. Coat. 2019, 132, $144-147$.

21. Schneider, M.; Kremmer, K.; Tabatabai, D.; Furbeth, W. Nano-sized zeolite particles as inhibitor carrier in plasma electrolytic oxide layers on AZ31. Mater. Corros. 2018, 2018, 971-977. [CrossRef]

22. Mojsilović, K.; Božović, N.; Stojanović, S.; Damjanović-Vasilić, L.; Serdechnova, M.; Blawert, C.; Zheludkevich, M.L.; Stojadinović, S.; Vasilić, R. Zeolite-containing photo Catalysts immobilized on aluminum support by plasma electrolytic oxidation. Surf. Interfaces 2021, 26, 101307. [CrossRef]

23. Hakimizad, A.T.A.; di Franco, F.; Raeissi, K.; Santamaria, M. Synergistic effect of W incorporation and pulsed current mode on wear and tribocorrosion resistance of coatings grown by plasma electrolytic oxidation on $7075 \mathrm{Al}$ alloy. Mater. Res. Express 2019, $6,106502$.

24. Lukiyanchuk, I.V.; Rudnev, V.S.; Andenko, N.A.; Kaidalova, T.A.; Panin, E.S.; Gordienko, P.S. Anodic-spark oxidation of aluminum alloy in tungstate electrolytes. Russ. J. Appl. Chem. 2002, 75, 573-578. [CrossRef]

25. Stojadinović, S.; Vasilić, R.; Radić, N.; Tadić, N.; Stefanov, P.; Grbić, B. The formation of tungsten doped $\mathrm{Al}_{2} \mathrm{O}_{3} / \mathrm{ZnO}$ coatings on aluminum by plasma electrolytic oxidation and their application in photocatalysis. Appl. Surf. Sci. 2016, 377, 37-43. [CrossRef]

26. Dondur, V.; Dimitrijević, R.; Kremenović, A.; Damjanović, L.; Kićanović, M.; Cheong, H.M.; Macura, S. Phase transformations of hexacelsians doped with Li, Na i Ca. Mater. Sci. Forum 2005, 494, 107-112. [CrossRef]

27. Rapheal, G.; Kumar, S.; Scharnagl, N.; Blawert, C. Effect of current density on the microstructure and corrosion properties of plasma electrolytic oxidation (PEO) coatings on AM50 Mg alloy produced in an alkaline electrolyte containing clay additives. Surf. Coat. Technol. 2016, 289, 150-164. [CrossRef]

28. Yerokhin, A.L.; Nie, X.; Matthews, A.; Dowey, S.J. Plasma electrolysis for surface engineering. Surf. Coat. Technol. 1999, 122, 73-93. [CrossRef]

29. Stojadinović, S.; Vasilić, R. Photoluminescence of $\mathrm{Ce}_{3}{ }^{+}$and $\mathrm{Ce}_{3}{ }^{+} / \mathrm{Tb}_{3}{ }^{+}$ions in $\mathrm{Al}_{2} \mathrm{O}_{3}$ host formed by plasma electrolytic xidation. J. Lumin. 2018, 203, 576-581. [CrossRef]

30. Stojadinović, S.; Ćirić, A. $\mathrm{Ce}_{3}{ }^{+} / \mathrm{Eu}_{2}{ }^{+}$doped $\mathrm{Al}_{2} \mathrm{O}_{3}$ coatings formed by plasma electrolytic oxidation of aluminum: Photoluminescence enhancement by $\mathrm{Ce}_{3}{ }^{+} \rightarrow \mathrm{Eu}_{2}{ }^{+}$energy transfer. Coatings 2019, 9, 819. [CrossRef]

31. Latha, P.; Prakash, K.; Karuthapandian, S. Enhanced visible light photocatalytic activity of $\mathrm{CeO}_{2} /$ alumina nanocomposite: Synthesized via facile mixing-calcination method for dye degradation. Adv. Powder Technol. 2017, 28, 2903-2913. [CrossRef] 
32. Ökte, A.N.; Yılmaz, Ö. La and Ce loaded $\mathrm{TiO}_{2}-\mathrm{ZSM}-5$ catalysts: Comparative characterization and photocatalytic activity investigations. Micropor. Mesopor. Mat. 2009, 126, 245-252. [CrossRef]

33. Bertuccioli, C.; Garzoni, A.; Martini, C.; Morri, A.; Randelli, G. Plasma electrolytic oxidation (PEO) layers from silicate/phosphate baths on Ti-6Al-4V for biomedical components: Influence of deposition conditions and surface finishing on dry sliding behavior. Coatings 2019, 9, 614. [CrossRef]

34. Jaspard-Mécuson, F.; Czerwiec, T.; Henrion, G.; Belmonte, T.; Dujardin, L.; Viola, A.; Beauvir, J. Tailored aluminum oxide layers by bipolar current adjustment in the plasma electrolytic oxidation (PEO) process. Surf. Coat. Technol. 2017, 201, 8677-8682. [CrossRef]

35. Huang, C.P.; Strumm, W. The specific surface area of $\gamma-\mathrm{Al}_{2} \mathrm{O}_{3}$. Surf. Sci. 1972, 32, 287-296. [CrossRef]

36. Hussein, R.O.; Northwood, D.O.; Nie, X. The influence of pulse timing and current mode on the microstructure and corrosion behavior of a plasma electrolytic oxidation (PEO) coated AM60B magnesium alloy. J. Alloys Compd. 2012, 541, 41-48. [CrossRef] 